\title{
Infrastructure Provision and Level of Socio-Economic Development in Rural Settlements of Niger State, Nigeria.
}

\author{
A. O. Sulyman \\ Department of Urban \& Regional Planning, \\ Federal University of Technology \\ Minna, Nigeria \\ E-mail: sulymanlance@gmail.com
}

\begin{abstract}
This study assesses the relationship between infrastructure provision and level of socio-economic development in rural settlements of Niger state of Nigeria. To achieve this aim, twenty- two (22) rural settlements were randomly selected. In all, a total of 1,792 rural dwellers were selected for the study. Multiple regression analysis was used to determine the relationship between infrastructure provision and socio-economic development. For this study, the dependent variable $Y$ (socio-economic development) is represented by road density while the independent variables are $X_{1}$ (Institutional variables); $X_{2}$ (Households infrastructure); $X_{3}$ (Welfare infrastructure) and $X_{4}$ (Accessibility factors). The result of multiple regression revealed that four factors were found to be significant in determining the level of socio-economic development in the selected twenty- two (22) settlements. These factors in order of importance were institutional infrastructure (71\%), Households' infrastructure (20\%), Accessibility factors (3.4) and welfare infrastructure $(0.1 \%)$. All these were found to have explained $94.5 \%$ level of socio-economic development in the study area. The study recommends increase in the level of participation of rural communities in development projects that have direct bearing on the welfare of rural populace. The rural communities should be involved right from the needs assessment stage, priority need identification, project implementation as well as monitoring and evaluation.
\end{abstract}

Keywords: Rural Infrastructure, Accessibility, Rural settlements, Rural Dwellers, Availability, Socio-economic development

Aims Research Journal Reference Format:

A. O. Sulyman (2018): Infrastructure Provision and Level of Socio-Economic Development in Rural Settlements of Niger State, Nigeria. Advances in Multidisciplinary \& Scientific Research Journal. Vol. 4. No.2, Pp 35-44

\section{BACKGROUND OF THE STUDY}

The importance of infrastructure to rural socio-economic life, according to Egunjobi (1987) can be seen from three perspectives. First, they stimulate economic activities. Second, they promote societal welfare of people and third, they prevent depopulation. He further argued that they are closely interrelated and all have to do with the quality of life of the rural populace. Also, stressing the importance of provision of infrastructure development, Madu (2007) observes that although diverse indicators are used to measure the level of rural development in a community, access to infrastructure is the most satisfactory yardstick of such assessment. This is because it shows at glance to what extent a community enjoys social amenities. Also, the importance of infrastructure lies in its capacity to help sustain daily activities, quality of life, and an economic base in rural settlements.

The specific problems of the rural settlement in Nigeria have always been recognized. Gana (1978) has earlier noted that the basic problem of most rural settlements in Nigeria was the desperate lack of essential amenities, such as medical facilities, efficient marketing services, adequate shopping facilities, good water and power supplies and good transport service. In the same vein, Egunjobi (1987) note that past and present approaches to rural development and most especially the infrastructure aspect have been piece-meal and devoid of physical planning concept and so are generally ineffective. Similarly, Madu (2007) has shown that institutional and articulated programmes for rural infrastructure development in the country are still lacking. As a result, while some rural communities have made significant advancement, others have lagged behind in the provision and access to infrastructure. In terms of the roles that rural settlements play in the economy of nation, infrastructure is meant to enhance the productive capacity and the quality of life of the rural areas and inhabitants. It is this way that the nation can actually achieve what might be regarded as the essence of rural development in the spatial economy with its characteristic rural-urban dichotomy (Areola, 1987). Infrastructure is often regarded as the underlying foundation or basic framework of a system (Abumere, et. al. 2002). 
Therefore, programme for poverty reduction in rural areas or indeed for overall development cannot succeed unless supported by infrastructure. Hence, access to infrastructure is usually used as a sensitive measure of poverty and rural performance. Madu (2007) supporting the above assertion, reports that availability of rural infrastructure can be effectively used as proxy indicators of the level of rural development in Nigeria. It is against this background that this study focuses on the effect of infrastructure provision on socio-economic development in some selected rural settlements in Niger state, Nigeria.

\section{IMPACT OF INFRASTRUCTURE ON DEVELOPMENT}

The impact of infrastructure on overall development of a community or a nation cannot be over emphasized. However, the precise linkages between infrastructure and development are still open to debate (World Bank, 1994). Sulyman (2013) discusses the relationship between provision of infrastructure and development in developing countries. Firstly, infrastructure can deliver major benefits in economic growth. McNeil (1993) argues that adequate infrastructure reduces the cost of production, which affects profitability, levels of output, and employment, particularly in small-scale business and that when infrastructure "works" productivity and labour increase and when it does not work, economic renewal can be postponed or even halted. Similarly, World Bank (1994) reports that good infrastructure raises productivity and lowers production cost, but it has to expand fast enough to accommodate growth. However, it has been established that infrastructure capacity grows step by step with economic output. In other words, a 1 percent increase in the stock of infrastructure is associated with 1 patent increase in growth domestic product(GDP) across all countries (World Bank, 1994; Fawehinmi, 2003).

Secondly, apart from economic considerations, inadequate infrastructure affects the health and well-being of citizens (McNeil, 1993).With infrastructure in place and performing, there is a great chance of healthier citizens. The most obvious example is the provision of improved water supply. Several diseases are caused by the scarcity of drinking and bathing water especially water-borne diseases like scabies; and water related diseases such as schistosomiasis, guinea worm and so on (Fawehinmi 2003). The scholar reports further that improved water and sanitation in developing countries on the average reduces diarrhea by 22 percent, round worm by 28 percent, guinea worm by 76 percent and schistosomiasis by 73 percent and that diarrhea death rate where typically 60 percent lower among children with adequate sanitation water. World Bank (1994) notes that poor management of solid wastes complicates urban street drainage and has been linked with the proliferation of disease bearing mosquitoes in standing water.

Thirdly, provision of infrastructure, its sustenance and flow of services from it all have direct effect on the level of poverty of individuals in the community (Fawehinmi, 2003). Thus, infrastructure affects the dimensions of poverty and in the developing countries, it has become a central poverty issue. Infrastructure has the power to determine the quality of life for residence, particularly in urban areas (McNeil, 1992). This is because neighborhoods often arise around infrastructure services and they contribute to community's cohesion and livelihood. Mabogunje (1993) reports that urban planning was also transformed to take account of the needs to extend infrastructure and services to individual plots of land within the city. Consequently, the links between urban infrastructural provision, urban land management, thus became an intricate and essential web in the development of modern city.

The importance of developing infrastructure has long been recognized as central in promoting economic growth (Ibem, 2009). The link between infrastructure and rural economic development has been recognized in the literature (Madu, 2007; Kanagawa and Nakata, 2008; Ogun, 2010; Cook, 2011; Badu et. al, 2013). Most of these researches did not focus on multi-dimensional aspects of rural economic development. Some set of the researchers analyses the relationship between rural electrification and rural economic development (Kirubi, Jacobson, Kammen and Mills, 2009; Kanagawa and Nakata, 2008). For example, Kanagawa and Nakata (2008) Assesses the relationship between access to electricity and advancement in a socioeconomic condition in rural areas of developing countries, using Assam state of India as a case study. The authors developed an energy-economic model in order to analyze the possibility of electrification through dissemination of electric lighting appliances as well as applied multiple regression analysis to estimate the socioeconomic condition, where they found out that increase in the supply of the rural electricity would improve rural economic development. Some other authors focused on telecommunication and rural economic development (Proenza, Bastidas-Buch, and Montero, 2001; Razak, 2009; Rashid and Rahman, 2009). Razak (2009) argued that with the increasing use of technology and ICT in daily lives of rural dwellers there is a great tendency for economic development as it is an effort to empower the rural communities.

In rural areas, infrastructure has wide ranging impacts on individuals, households and communities both in terms of income and other quality of life indicators. There are both direct and indirect benefits from infrastructure development and it is important to consider the indirect benefits in decision-making about infrastructure project. Education, for example, can affect income and health both of that in turn affect quality of life. They are also strong social benefits from infrastructure that needs to be taken into account. 
Economic benefit such as increase income, employment, productivity gain, better income distribution and opportunity for diversification are obvious. Social benefits such as time savings, school enrolment levels, access to health services, environmental improvement, skill development, capacity building, improved information and gender impacts are less transparent, but in the longer term maybe as or more effective in poverty reduction because they lead to sustained improvements in quality of life independent of income sources.(African Development Bank, 2000).

\section{STUDY AREA}

Nigeria is located between latitudes $820^{\prime} \mathrm{N}$ and $1130^{\prime} \mathrm{N}$ and longitude $330^{\prime} \mathrm{E}$ and $720^{\prime} \mathrm{E}$. The state is situated in the north central geo-political zone and shares its border with Republic of Benin (West) ,Zamfara state (North), Kebbi (North-West), Kogi, (South), kwara (South-West), Kaduna (North-East) and the Federal Capital Territory FCT (SouthEast) (Niger state Government, 2004) Figure 1 shows the location of Niger State in Nigeria. The state covers a total land area of about 76,000 sq. km, or about 9 percent of Nigeria's total land area. This makes the state the largest in the country (Baba, 1993, online Nigeria, 2003.) At inception in 1967, the state had only eight local Government Areas (LGAs), however, with the series of state and local government creation exercises and boundary adjustments between 1979 and 1996. The number of LGAs in the state has increased to twenty-five.

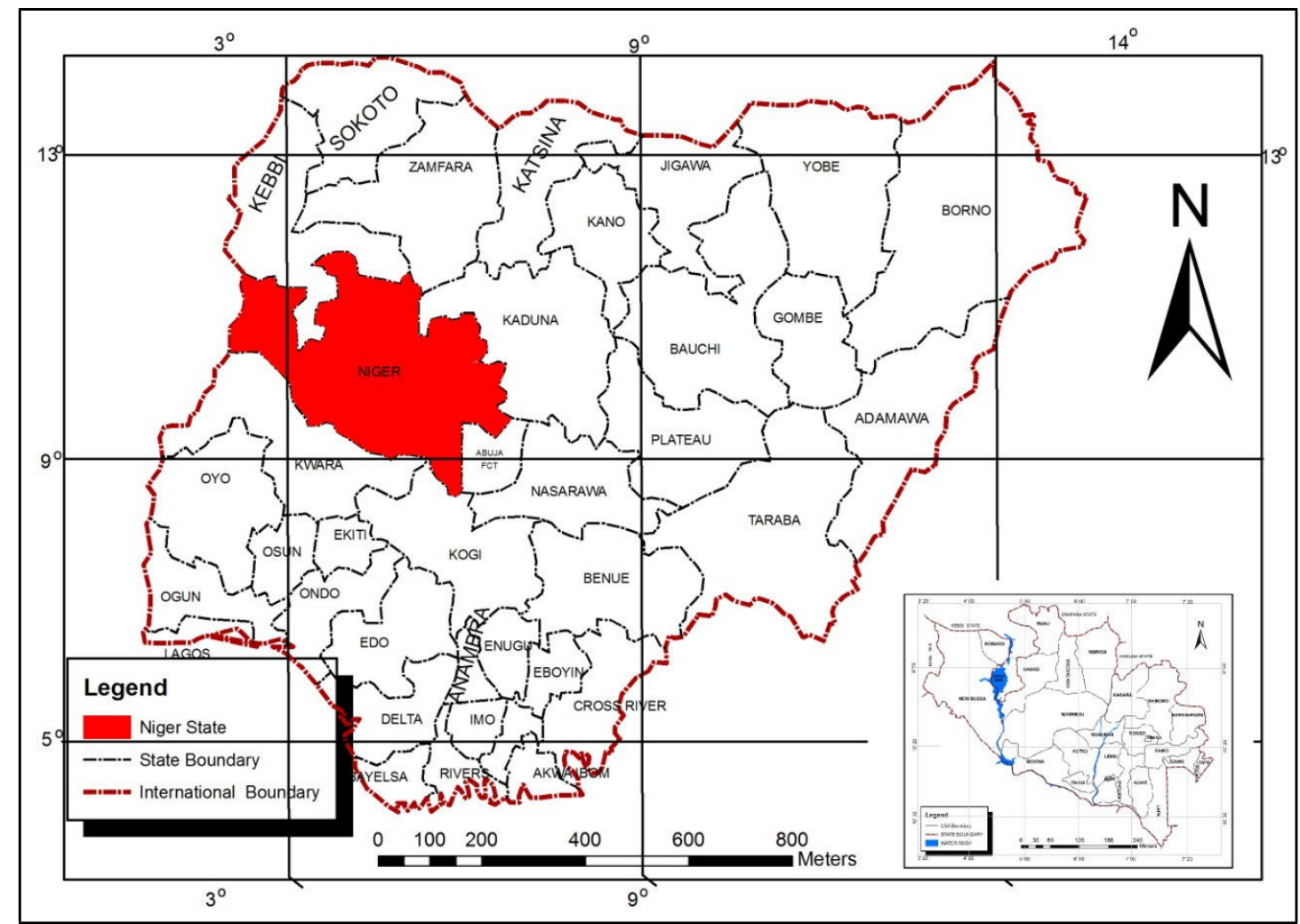

Figure 1: Location of Niger State in Nigeria.

Source: Federal ministry of lands, housing and urban Development, Abuja.

In terms of human settlements, the majority of the people of the state reside in rural Areas. According to Baba (1993) for example, 90 percent of the state population were rural residents. Similarly, following 1991 population census Morenikeji, et al (2000) reported that there were 2,371 rural settlements with a total population with a total population of 1,868,939 and eight urban settlements with a combined population 552,642 in the state making the state essentially rural. According to Baba (1993), the characteristic rural settlements in the Nupe cultural area are of the nucleated type in which each settlement consists of many compounds built in close quarters and each compound houses a family which is an independent production/consumption unit. On the other hand, outside Nupe territory, dispersed rural settlements predominate in northern local government areas of Mariga, Magama, Borgu and Shiroro in which the residents commonly form one unit of production/consumption. Some of the major urban settlements in the state include Minna the State Capital, Bida, Suleja and Kontagora. 


\section{RESEARCH METHODS}

For this study, 22 local government areas were considered for the purpose of selecting the rural settlements. The 22 local government areas were further stratified into two: namely completely rural local government areas consisting of all settlements having population below 20,000 including their headquarters, while the partially rural local government areas have only their headquarters with population of more than 20,000 with remaining settlements having population of less than 20,000. The selection of settlements was done by ranking all the settlement in each local government in descending order and selecting the first settlement with population of less than 20,000 . In all, a total of 22 settlements were selected traversing 22 local government areas.

Multiple regression analysis was used to determine the relationship between infrastructure provision and level of socio-economic development in the selected rural settlements. The multiple regression equation is from the form:

$Y_{i}=a+b_{1} x_{1}+b_{2} x_{2}+---b_{n} x_{n}+e$

Where

$\mathrm{Y}_{\mathrm{i}}=$ dependent variable

$\mathrm{a}=\mathrm{a}$ constant (intercept)

$b_{1} \ldots b_{n} \ldots . . .=$ regression coefficients

$\mathrm{x}_{1}-\mathrm{x}_{\mathrm{n}} \ldots \ldots=$ independent variables

$\mathrm{e}=$ error term

\section{RESULTS AND DISCUSSION}

\subsection{Inventory of Selected Infrastructure in the Rural Settlements}

The inventory of selected infrastructure provision in the selected rural settlements of Niger State is presented in Table 1. The selected infrastructure includes health, education and water supply. The result shows that twelve (12) settlements had one (1) general/rural hospital each, while none was recorded for Agwara, Doko, Enagi, Gbajibo, Gulu, Mashegu, Paiko, Rafin Gora, Tegina and Wawa, were not provided with any. In terms of comprehensive health centre, Agwara, Badeggi, Bangi, Doko, Enagi, Gbajibo, Kuta, Mashegu, Paiko and Sabon Wuse had one (1) each while other rural settlements, were not provided. In terms of clinic provision, Kuta, Paiko, Sarkin Pawa and Wawa had two (2) clinics each. Other settlements had one (1) each except for Agwara, Bangi, Enagi, Gbajibo, Nasko, Sabon Wuse and Tungan Magajiya settlements that had none. In terms of dispensary, the survey shows that Agwara, Bangi, Rafin Gora and Wawa had one (1) each.

The survey of educational facilities revealed that only Tungan Magajiya had one (1) Tertiary institution. However Kuta had the highest number of secondary schools with four (4) followed by Paiko and Tungan Magaijya that had three (3) each. In terms of primary schools, Kuta had eight (8), followed by Doko, Paiko and Wushishi with six (6) each, while by Tunga Magajiya had five (5). However, Rafin Gora had one (1) primary school which is the lowest recorded. The survey of water supply, revealed that Gawu and Wushishi had two (2) public taps each, while Badeggi, Doko, Enagi, Kuta, Kutiriko, Lemu, Paiko, Sabon Wuse and Tegina had one (1) each. Other settlements had no public tap. In terms of public boreholes, Kuta had twenty two (22), followed by Doko and Paiko with ten (10) each, while Sabon Wuse had nine (9), Maikunkele had eight (8). Other settlements had less than eight (8). The health and educational facilities as well as water supply in the rural settlements are shown in Plates I, II and III respectively. 
Advances In Multidisciplinary

Aiss \& Scientifie Research

Vol. 4 No. 3, September 2018

Table 1: Inventory of Infrastructure in Selected Rural Settlements of Niger State

\begin{tabular}{|c|c|c|c|c|c|c|c|c|c|c|}
\hline \multirow[b]{2}{*}{ S/No } & \multirow{2}{*}{$\begin{array}{l}\text { SETTLEM } \\
\text { ENTS }\end{array}$} & \multicolumn{9}{|c|}{ INFRASTRUCTURE } \\
\hline & & $\begin{array}{c}\text { General/Rural } \\
\text { Hospital }\end{array}$ & $\begin{array}{c}\text { Comprehensive } \\
\text { Health Centre }\end{array}$ & Clinic & Dispensary & $\begin{array}{c}\text { Tertiary } \\
\text { Institution }\end{array}$ & $\begin{array}{c}\text { Secondary } \\
\text { School }\end{array}$ & $\begin{array}{r}\text { Primary } \\
\text { School }\end{array}$ & $\begin{array}{l}\text { Public } \\
\text { Taps }\end{array}$ & $\begin{array}{c}\text { Public } \\
\text { Boreholes }\end{array}$ \\
\hline 1 & Agwara & & 1 & & 1 & & 1 & 4 & & 5 \\
\hline 2 & Badeggi & 1 & 1 & 1 & & & 1 & 3 & 1 & 6 \\
\hline 3 & Bangi & 1 & 1 & & 1 & & 1 & 3 & & 2 \\
\hline 4 & Doko & & 1 & 1 & & & 2 & 6 & 1 & 10 \\
\hline 5 & Enagi & & 1 & & & & 1 & 4 & 1 & 6 \\
\hline 6 & Gawu & 1 & & 1 & & & 2 & 3 & 2 & 6 \\
\hline 7 & Gbajibo & & 1 & & & & 1 & 2 & & 1 \\
\hline 8 & Gulu & & & 1 & & & 2 & 4 & & 2 \\
\hline 9 & Kuta & 1 & 1 & 2 & & & 4 & 8 & 1 & 22 \\
\hline 10 & Kutiriko & 1 & & 1 & & & 1 & 2 & 1 & 5 \\
\hline 11 & Lemu & 1 & & 1 & & & 2 & 4 & 1 & 5 \\
\hline 12 & $\begin{array}{l}\text { Maikunkel } \\
\mathrm{e}\end{array}$ & 1 & & 1 & & & 2 & 3 & & 8 \\
\hline 13 & Mashegu & & 1 & 1 & & & 1 & 2 & & 2 \\
\hline 14 & Nasko & 1 & & & & & 1 & 2 & & 4 \\
\hline 15 & Paiko & & 1 & 2 & & & 3 & 6 & 1 & 10 \\
\hline 16 & $\begin{array}{l}\text { Rafin } \\
\text { Gora }\end{array}$ & & & 1 & 1 & & 1 & 1 & & 1 \\
\hline 17 & $\begin{array}{l}\text { Sabon } \\
\text { Wuse }\end{array}$ & 1 & 1 & & & & 2 & 4 & 1 & 9 \\
\hline 18 & $\begin{array}{l}\text { Sarkin } \\
\text { Pawa }\end{array}$ & 1 & & 2 & & & 1 & 4 & & 6 \\
\hline 19 & Tegina & & & 1 & & & 1 & 4 & 1 & 4 \\
\hline 20 & $\begin{array}{l}\text { Tungan } \\
\text { Magajiya }\end{array}$ & 1 & & & & 1 & 3 & 5 & & 2 \\
\hline 21 & Wawa & & & 2 & 1 & & 2 & 4 & & 2 \\
\hline 22 & Wushishi & 1 & & 1 & & & 1 & 6 & 2 & 4 \\
\hline
\end{tabular}

Source: Author's fieldwork, 2011 


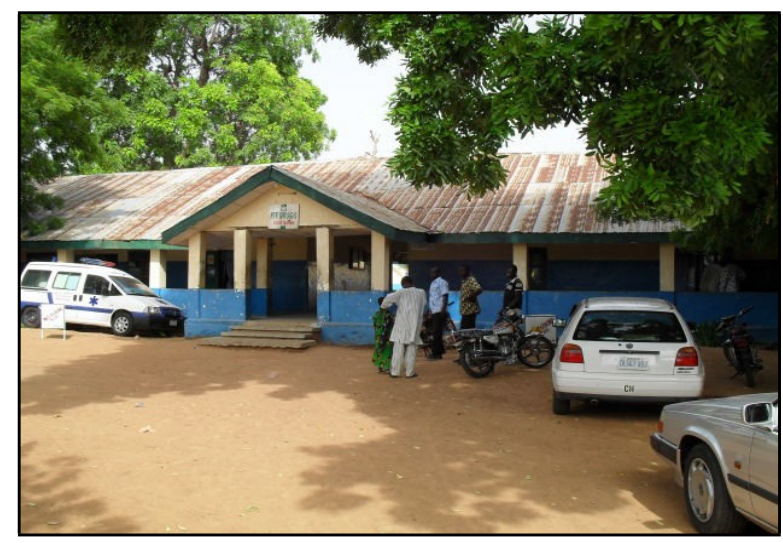

Plate I: General Hospital in Tungan Magajiya Source: Author's fieldwork, 2011

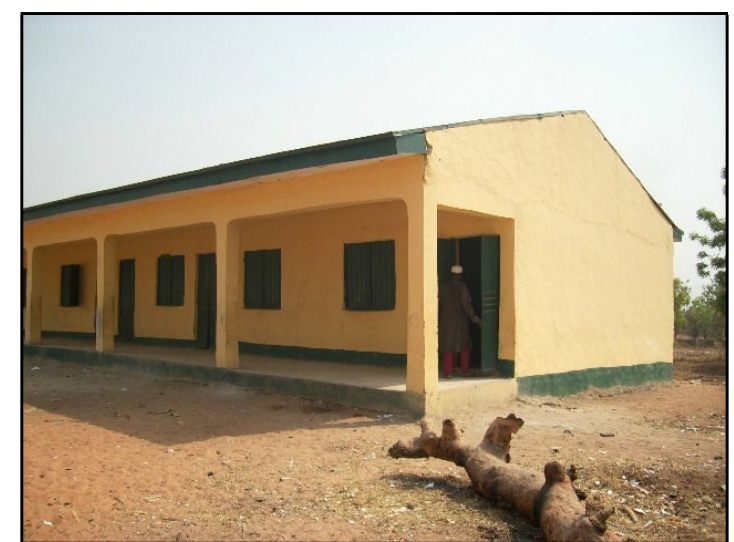

Plate II: A new primary school structure at Kitiriko Source: Author's fieldwork, 2011

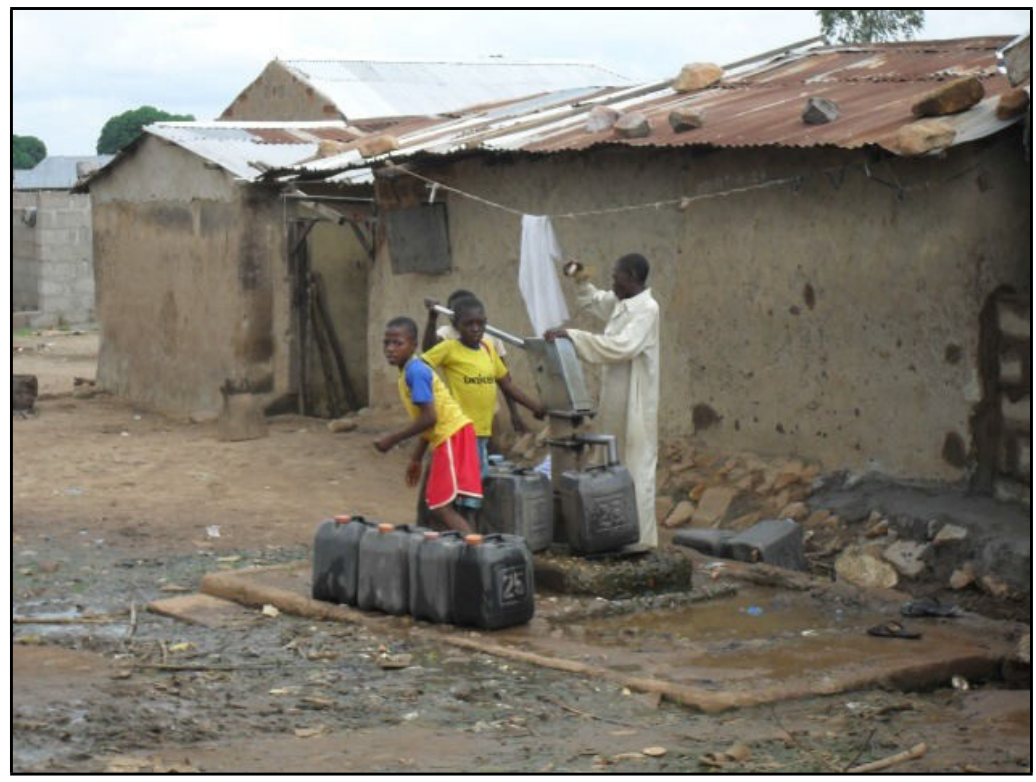

Plate III: Public Borehole in Bangi

Source: Author's fieldwork, 2011

5.2 Infrastructural Provision and Level of Socio-Economic Development

It should be noted that rather than using all the twenty (20) variables as input into the regression model the result of the factor analysis was used. Adedayo (1989) and Olawepo (1996) used the result of factor analysis as inputs for the regression model in their works. This method was therefore, employed in this work to assist in deriving a new model which can be used for predicting pattern of infrastructure-induced pattern of socioeconomic development in the twenty-two selected settlements in the study area.

Factor analysis was used to reduce the size of the original data set so as extract a small set of factors which significantly account for most of the variance in the original set. Consequently, a factor analysis with varimax rotation was applied to the $20 \times 20$ data matrix involving infrastructural and socio-economic variables as shown in Table 2. 


\section{Advances In Multidisciplinary}

Table 2: List of Infrastructural and Socio-Economic Variables

\begin{tabular}{|l|l|}
\hline Variables & \multicolumn{1}{|c|}{ Definition } \\
\hline$X_{1}$ & Road density in Km² \\
$X_{2}$ & Number of health facilities per settlement \\
$X_{3}$ & Distance in Km travelled to reach the health facilities \\
$X_{4}$ & Number of educational facilities per settlement \\
$X_{5}$ & Distance in Km travelled to reach the educational facilities \\
$X_{6}$ & Number of water facilities per settlement \\
$X_{7}$ & Distance in Km travelled reach the water facilities \\
$X_{8}$ & Number of settlements connected to National Grid ( electricity) \\
$X_{9}$ & Percentage of households with formal education \\
$X_{10}$ & Percentage of households with refrigerator \\
$X_{11}$ & Number of administrative facilities per settlement \\
$X_{12}$ & Number of social institutions per settlement \\
$X_{13}$ & Number of communication facilities per settlement \\
$X_{14}$ & Percentage of households with non-formal education \\
$X_{15}$ & Percentage of households with radio \\
$X_{16}$ & Percentage of households with TV set \\
$X_{17}$ & Percentage of households with electric iron \\
$X_{18}$ & Percentage of households with electric fan \\
$X_{19}$ & Number of financial institutions per settlement \\
$X_{20}$ & Number of recreational facilities per settlement \\
\hline
\end{tabular}

Source: Author's fieldwork, 2011

However, in the regression analysis used for the study, the dependent variable $Y$ (socio-economic development) is represented by road density while the independent variables are $X_{1}$ (Institutional infrastructure), $X_{2}$ (Households infrastructure), $X_{3}$ (Welfare infrastructure) and $X_{4}$ (Accessibility factor). Road density was considered an adequate indicator of level of socio-economic development in the state because it has been established that there is a close relationship between density of road network, density of population, settlement growth and level of economic development (White and Senior, 1983 cited in Aderamo, 2007). Besides, road density is the only variable component of factor 5 and has the highest factor loading of 0.944 among all the component variables derived from factor analysis (see Table 2).

Table 3: Substantial Factor Loading (Varimax)

\begin{tabular}{|c|c|l|c|}
\hline Factor & Variable & \multicolumn{1}{|c|}{ Description } & Loadings \\
\hline Factor 1 & $X_{13}$ & Number of communication facilities per settlement & 0.879 \\
& $X_{19}$ & Number of financial institutions per settlement & 0.869 \\
& $X_{12}$ & Number of social institutions per settlement & 0.859 \\
& $X_{9}$ & Percentage of households with formal education & 0.769 \\
& $X_{14}$ & Percentage of households with non-formal education & -0.729 \\
& $X_{11}$ & Number of administrative facilities per settlement & 0.550 \\
Factor 2 & $X_{18}$ & Percentage of households with electric fan & 0.859 \\
& $X_{17}$ & Percentage of households with electric iron & 0.855 \\
& $X_{15}$ & Percentage of households with radio & 0.796 \\
& $X_{8}$ & Number of settlements connected to National Grid (electricity) & 0.773 \\
& $X_{16}$ & Percentage of households with TV set & 0.734 \\
Factor 3 & $X_{10}$ & Percentage of households with refrigerator & 0.691 \\
& $X_{20}$ & Number of recreational facilities per settlement & 0.895 \\
& $X_{6}$ & Number of water facilities per settlement & 0.840 \\
& $X_{2}$ & Number of health facilities per settlement & 0.838 \\
Factor 4 & $X_{4}$ & Number of educational facilities per settlement & 0.707 \\
& $X_{5}$ & Distance in Km travelled to reach the educational facilities & 0.928 \\
& $X_{3}$ & Distance in Km travelled to reach the health facilities & 0.910 \\
Factor 5 & $X_{7}$ & Distance in Km travelled reach the water facilities & 0.853 \\
\hline
\end{tabular}

Source: Computer output from Author's fieldwork, 2011. 


\section{Advances In Multidisciplinary

In the selection of variables, efforts were made to comply with the basic assumptions of the regression model notably, the effects of independent variables are additive, the presence of non-collinearity and measurements intervals. Suffice to say that the factor scores used as input into regression model are orthogonal to one another and therefore independent. The summary of the result of the regression analysis is shown in Table 4.

Table 4: Summary of the result of Regression Analysis

\begin{tabular}{|c|c|c|c|c|c|c|c|}
\hline $\begin{array}{c}\text { Independent } \\
\text { Variables }\end{array}$ & $\begin{array}{c}\text { Regression } \\
\text { Coefficient }\end{array}$ & $\begin{array}{c}\text { Standard } \\
\text { Error }\end{array}$ & $\mathbf{R}$ & $\mathbf{r}^{\mathbf{2}}$ & $\begin{array}{c}\text { \% of } \\
\text { Contribution }\end{array}$ & $\begin{array}{c}\text { T } \\
\text { Value }\end{array}$ & $\mathbf{P}$ Value \\
\hline Intercept & 13816.516 & $12 . .367$ & & & & 1117.22 & 0.000 \\
\hline$X_{1}$ & 1865.305 & 12.370 & 0.842 & 0.710 & $71 \%$ & 150.789 & 0.000 \\
\hline$X_{2}$ & 991.740 & 12.370 & 0.954 & 0.910 & $20 \%$ & 81.171 & 0.000 \\
\hline$X_{4}$ & -405.250 & 12.370 & 0.972 & 0.944 & $3.4 \%$ & -32.760 & 0.000 \\
\hline$X_{3}$ & 43.948 & 12.370 & 0.972 & 0.944 & $0.1 \%$ & 3.553 & 0.000 \\
\hline
\end{tabular}

Source: Computer Output from Author's fieldwork, 2011

$Y$ represents Socio-economic development (Road density)

$\mathrm{X}_{1}$ represents Institutional infrastructure

$\mathrm{X}_{2}$ represents Households infrastructure

$\mathrm{X}_{3}$ represents Welfare infrastructure

$\mathrm{X}_{4}$ represents Accessibility factor

In the explanation of factor(s) that determine the level of socio-economic development in the twenty two selected settlements in the study area, four factors are found to be significant. Thus, variables $X_{1}$ (Institutional infrastructure), $X_{2}$ (Households infrastructure), $X_{4}$ (Accessibility factor) $X_{3}$ and (Welfare infrastructure) were together found to explain $94.5 \%$ of the level of socio-economic development in the selected settlements in the study area.

An examination of Table 3 reveals that variable $X_{1}$ which is Institutional infrastructure is an important factor influencing socio-economic development in the study area. The components of this factor namely communication facilities, financial institutions, social institutions and administrative facilities have been found to influence the level of socio-economic development of the selected settlements in the study area. The correlation co-efficient of this variable $\left(\mathrm{X}_{1}\right)$ is 0.842 with co-efficient of determination $\left(r^{2}\right)$ of 0.710 , signifying that about $71.0 \%$ of the variance is associated with the Institutional Infrastructure.

Households' infrastructure which is variable $X_{2}$ is another important factor that can be used to explain the level of socioeconomic development of the selected settlements in the study area. The components of this factor include households with electric fan, electric iron, radio, television set and refrigerator. These variables which loaded positively high on the factor and together with the availability of electricity serve the welfare of the households in the selected settlements and thus influence the level of socio-economic development in the study area. The correlation co-efficient is found to be 0.954 with co-efficient of determination $\left(r^{2}\right)$ of 0.910 , indicating that $20.0 \%$ of its variance is associated with Households' infrastructure.

The third important factor is variable $X_{4}$ which is Accessibility factor. The component variables of the factor namely distance in kilometers covered to reach health, educational and water facilities which all loaded positively high on the factor are all significant in influencing the level of socio-economic development in the selected settlements. The correlation co-efficient of this factor is found to be 0.972 with co-efficient of determination $\left(r^{2}\right)$ of 0.944 indicating $3.4 \%$ of the variance is associated with Accessibility factor.

Welfare infrastructure which is variable $X_{3}$ factor is also important in explaining the level of socio-economic development of the selected settlements in the study area. The component variables of the factor are recreational, health, educational and water facilities. There is no doubt that the presence of all these in any settlements is an indication of socio-economic development. Consequently, the factor has been identified to influence the level of socio-economic development of the selected settlements in the study area. The factor has a correlation co-efficient of 0.972 with co-efficient of determination $\left(r^{2}\right)$ of 0.944 indicating that $0.1 \%$ of the variance is associated with the Welfare infrastructure. 
In all, four variables together accounted for about $94.5 \%$ of the total variance in the explanation of factors responsible for road density development which has been used as a measure of socio-economic development in the study area. The explanatory regression equation can thus be written as:

$$
\begin{aligned}
& Y=13816.516+1865.305 X_{1}+991.740 X_{2}+405.20 X_{3}+43.948 X_{4} \\
& R^{2}=94.5 \% \quad S E=523.51374
\end{aligned}
$$

The implication of this is that an increase in road density in the selected settlements in the study area is expected to have impact on provision of more institutional infrastructure such as administrative and communication facilities as well as financial and social institutions. This will also lead to provision of more Households' infrastructure such as electric fans, radio, television set and refrigerator. Similarly, the increase in road density is also expected to improve accessibility to health, educational and water facilities among others in the selected settlements, hence the importance of Accessibility factor. Lastly, the increase in the road density is expected to attract more Welfare infrastructure such as recreational, health, educational and water facilities to selected settlements.

\section{CONCLUSION AND RECOMMENDATIONS}

There is no doubt that the level of socio-economic development of rural settlements is a function of the services enjoyed by the people. Consequently, the study has revealed that provision of infrastructure has impact on socio-economic development of the rural settlement in Niger, State. From the forgoing it was observed that four factors were found to be significant in determining the level of socio-economic development in the selected twenty two (22) settlements. These factors in order of importance were Institutional infrastructure $(71 \%)$, Households' infrastructure $(20 \%)$, Accessibility factor $(3.4 \%)$ and welfare infrastructure $(0.1 \%)$. All these were found to have explained $94.5 \%$ level of socio-economic development in the study area. The study recommends that the state and local governments should put in place deliberate efforts to change policies concerning the development of infrastructure by ensuring an increase in the level of participation of rural communities in development projects that have direct bearing on the welfare of rural populace. The rural communities should be involved right from the needs assessments stage, priority need identification, project implementation as well as monitoring and evaluation.

Notwithstanding the various findings in this study, there are still some key issues, which would require the attention of future research. One important variable to be considered as a factor influencing provision of infrastructure in rural settlements is political variable. This should include the influence of politicians in the decisions concerning what goes to where and how much. This can be investigated in future research. There is also the need for further studies that consider policy implication or policy evaluation on classification of settlements based on infrastructure for the development of human settlements. This will assist in formulation of rural infrastructure provision policy. The relationship between infrastructure provision and socio-economic development of some selected settlements in the rural areas of Niger State has been established, nevertheless, similar study is advocated elsewhere to give room for inter-regional; comparison and with the aim of verifying claims reached from this study.

\section{REFERENCES}

1. Abumere, S.I., Okafor, S.I. Oluwasola, O. (2002), Rural Infrastructure and Development process in rural Nigeria. Research Report No. 36, Development policy centre. Ibadan, Nigeria.

2. Adedayo, A. (1988), "Spatial Ecology of Social Deprivation in a Rural Nigeria Environment" International Journal of Environmental Studies.31:45 - 53

3. Adedayo, A. (1989), "Spatial Inequalities in Economic Development: The Case of Part South-Western Nigeria" Unpublished PhD Thesis, University of Ilorin, Ilorin, Nigeria.

4. Aderamo, A. J. (2007), "Transport and Socio-Economic Development in Kwara State, Nigeria" The Nigerian Journal of Economic and Social Studies. 49(1): 27-44

5. Areola, O. (1987), "The concept and definition of Rural and infrastructure Development", paper presented at the workshop on physical planning and rural infrastructure Development in Nigeria organized by NISWER, Ibadan.

6. Baba, J. M. (1993), "Niger State" in Udo, R.K And Mamman, A.B, (eds) Nigeria: Giant in the Tropics (volume 2) Lagos: Gabumo Publishing company Ltd. pp. $331-345$.

7. Badu, E., Owusu-Manu, D., Edwards, D. J., Adesi, M., \& Lichtenstein, S. (2013). Rural infrastructure development in the Volta region of Ghana: barriers and interventions. Journal of Financial Management of Property and Construction, 18(2), 142-159. https://doi.org/10.1108/JFMPC-11-2012-0040

8. Cook, P. (2011). Infrastructure, rural electrification and development. Energy for Sustainable Development, 15(3), 304-313. https://doi.org/10.1016/j.esd.2011.07.008 
9. Egunjobi, L. (1987), "Regional Approach to Rural Infrastructure Development Planning" Paper Presented at the Workshop on Physical Planning and Rural Infrastructure Development in Nigeria, Organised by NISER, Ibadan, June 22-26,1987

10. Fawehinmi, Y. (2003), "Infrastructure and Human Development: A General Introduction" in Fawehinmi, Y. (ed.) Urban Finance and Infrastructural Development in Nigeria. Ibadan: Institute of Land Economics and Atlantis Books.pp.1 - 13.

11. Gana, J.A (1978), "Rural Settlements" in Oguntoyinbo, J.S, Areola, O.O. and Filani, M. (eds), A Geography of Nigerian Development. Ibadan: Heinemann Educational Books (Nig.) Ltd. pp.138 - 155.

12. Ibem, E. O. (2009). Community-led infrastructure provision in low-income urban communities in developing countries: A study on Ohafia, Nigeria. Cities, 26(3), 125-132. https://doi.org/10.1016/j.cities.2009.02.001

13. Kanagawa, M., \& Nakata, T. (2008). Assessment of access to electricity and the socio-economic impacts in rural areas of developing countries. Energy Policy, 36(6), 2016-2029. https://doi.org/10.1016/j.enpol.2008.01.041

14. Kirubi, C., Jacobson, A., Kammen, D. M., \& Mills, A. (2009). Community-Based Electric Micro-Grids Can Contribute to Rural Development: Evidence from Kenya. World Development, 37(7), 1208-1221. https://doi.org/10.1016/j.worlddev.2008.11.005

15. Mabogunje, A (1993), "Infrastructure: The Crux of Modern Urban Development" The Urban Age: 1(3):3.

16. Madu, I.A. (2007), "The Underlying Factors of Rural Development patterns in the Nsukka Region of Southeastern Nigeria" Journal of Rural and Community Development 2:110-122.

17. McNeil, M. (1993), "The Changing Nature of Infrastructure" The Urban Age.1(3): 1-4.

18. Morenikeji, W, Sanusi, Y.A. and Jinadu, A.M (2000), The Role of Private Voluntary Organisations in Community and Settlement Development in Niger State. A Research Report submitted to the Centre for Research and Documentation, Kano, Nigeria.p.5.

19. Niger State Government (2004), Niger Economic Empowerment and Development Strategy (NSEEDS), Ministry of Finance and Economic Planning, Minna

20. Ogun, T. P. (2010). Infrastructure and poverty reduction: implications for urban development in Nigeria. Helsinki: WIDER. Retrieved from http://hdl.handle.net/10419/54001

21. Online Nigeria (2003), Nigeria: Niger State On-line. Accessed on 29, April 2009 from http://www.onlinenigeria.com/links/Niger-adv.asp.

22. Proenza, F. J., Bastidas-Buch, R., \& Montero, G. (2001). Telecenters for socioeconomic and rural development in Latin America and the Caribbean. Washington DC: Inter-American Development Bank.

23. Rashid, A. T., \& Rahman, M. (2009). Making profit to solve development problems: the case of Telenor AS and the Village Phone Programme in Bangladesh. Journal of Marketing Management, 25(9-10), 1049-1060. https://doi.org/10.1362/026725709X479363

24. Razak, N. A. (2009). Empowering the rural communities via the telecentres. European Journal of Social Sciences, 9(3), 425-432.

25. Sulyman, A.O. (2013), "Towards Better Performance of Infrastructure Management in Developing Countries Environmental Issues 6(1):137-143.

26. White, H. P. and Senior, M. L. (1983), Transport Geography, Longman Scientific and Technical England.

27. World Bank, (1994), World Development Report 1994: Infrastructure for Development. New York; Oxford University Press.pp. $13-36$. 